Online: http://journal.uny.ac.id/index.php/jppfa

\title{
PEMBENTUKAN KARAKTER MANDIRI BAGI PENYANDANG DISABILITAS KECERDASAN DALAM KAPASITAS KEMANUSIAAN
}

\author{
Mumpuniarti \\ Fakultas Ilmu Pendidikan Universitas Negeri Yogyakarta \\ mumpuni@uny.ac.id
}

\begin{abstract}
Abstrak
Penyandang disabilitas kecerdasan adalah salah satu kajian terhadap individu yang diasumsikan dalam menuju kemandirian secara spesifik terhambat. Hambatan itu diperlukan suatu intervensi yang sesuai dengan kapasitas kemanusiaan dan konteks dengan lingkungan kehidupan yang sehari-hari dialami oleh mereka sebagai peserta didik. Lingkungan yang dimulai dari level mikro sampai level makro, sehingga proses sosialisasi berlapis-lapis dari yang terdekat dan terkecil dengan kehidupan peserta didik sampai menuju lingkungan kehidupan yang terluas. Lingkungan itu juga sebagai bagian dari kehidupan awal anak sampai ke kehidupan di masa dewasa, yaitu kehidupan di keluarga, sekolah, dan masyarakat. Berbagai level dan area lingkungan kehidupan tersebut terdapat substansi-substansi cara kehidupan mandiri yang harus dipelajari oleh mereka yang kategori disabilitas kecerdasan. Konteks dalam belajar agar memiliki karakter mandiri terbentuk karena kondisi yang harus dihadapi secara langsung dengan praktek berlatih untuk hidup. Praktek berlatih untuk hidup sebagai sarana belajar yang konkrit dan nyata dalam rangka mengatasi kelemahan konseptual, sosial, dan keterampilan adaptif bagi mereka. Dengan demikian, pembentukan karakter mandiri melalui pembiasaan belajar cara hidup yang langsung di tiga area lingkungan.
\end{abstract}

Kata kunci:

\section{INDEPENDENT-CHARACTER BUILDING FOR INTELLIGENCE DISABILITIES IN THE HUMANITY CAPACITY}

\author{
Mumpuniarti \\ Fakultas Ilmu Pendidikan Universitas Negeri Yogyakarta \\ mumpuni@uny.ac.id
}

\begin{abstract}
People with intelligence disabilities have been the subjects of the study of individuals who are assumed to be specifically inhibited toward independence. Barriers require an intervention appropriate with the capacity of the humanitarian and environmental context of everyday life experienced by them as learners. Environment is from the micro level to the macro level, so that the process of socialization is in the layers from the closest and smallest one with the lives of young people up to the widest life environment. The environment is also as part of a child's early life up to his/her adulthood, which is life in the family, school, and community. Various levels and areas of the life environment are substances of independent way of life that should be studied by those disability categories of intelligence. Learning context in order to have an independent character is formed because of the conditions that must be dealt with directly with training practice for life. Practicing the practice for life is as a learning facility that is concrete and tangible in order to overcome the weakness of conceptual, social, and adaptive skills for them. Thus, building the independence character is through the learning habituation of how to live directly in the three environmental areas.
\end{abstract}

Keywords: 


\section{PENDAHULUAN}

Penyandang disabilitas kecerdasan atau yang lebih sering disebut tunagrahita adalah suatu individu yang memiliki keterbatasan-keterbatasan. Keterbatasan kecerdasan yang berakibat kekurangan (defisit) di bidang konseptual, sosial, dan keterampilan adaptif. Keterbatasan tersebut berimplikasi pada masalah kemandirian mereka di masyarakat. Penelitian Pratiwi (2011, p. x) bahwa para alumni dari dua yayasan yang membina tunagrahita sebagai tempat penelitian belum mampu memandirikan tunagrahita secara penuh. Fenomena ini sebagai suatu titik awal pengkajian tentang urgensinya kemandirian bagi tunagrahita/penyandang disabilitas intelektual. Keterbatasan pada aspek konseptual, sosial, dan keterampilan adaptif sebagai problem utama untuk mandiri di masa dewasa dalam kehidupan masyarakat.

Problem kemandirian pada penyandang disabilitas kecerdasan dilatarbelakangi oleh suatu harapan bahwa hasil pendidikan muaranya adalah kemandirian. Kemandirian dalam kehidupan masyarakat dibutuhkan suatu kepribadian yang adaptif dan fungsional dalam budaya masyarakat. Masyarakat yang selalu berubah menuntut para anggotanya juga berubah untuk menyesuaikan dengan budaya masyarakat. Untuk itu, mandiri dalam kategori perilaku adaptif sesuai budaya adalah juga harapan yang bersifat manusiawi, karena kapasitas manusia dari mereka yang dikategorikan disabilitas kecerdasan perlu diberi peluang untuk aktualisasi diri dalam budaya. Masyarakat yang selalu berubah dalam budaya menjadikan suatu tantangan untuk dipilihkan perilaku adaptif yang urgen bagi disabilitas kecerdasan agar supaya mereka tetap mampu mandiri dalam budaya masyarakat yang selalu berubah.

Pembentukan karakter mandiri adalah suatu alternatif optimalisasi kemanusiaan bagi disabilitas kecerdasan.Karakter sebagai dasar pembentukan kepribadian lebih diutamakan. Hal-hal yang memberi nilai bahwa untuk suatu tugas-tugas dalam kehidupan sehari-hari harus berusaha dikerjakan menjadi tekanan pembiasaan, jika menemui kesulitan dalam mengatasi problem kehidupan sehari-hari mereka dibiasakan untuk mencari informasi dan bantuan untuk menyelesaikan terhadap problem yang dihadapi tersebut.Cara mencari itulah yang menjadi fokus karakter mandiri dan problem-problem yang perlu diselesaikan juga fokus pada aktivitas kehidupan seharihari.Mereka juga dibiasakan untuk memiliki daya tahan atau nilai keuletan dalam berusaha.Nilai itu juga sebagai pendorong karakter mandiri, karena tanpa pendorong tidak ada artinya dinamika kehidupan bagi mereka yang tergolong disabilitas kecerdasan. Beberapa kategori disabilitas kecerdasan yang semakin berat diarahkan untuk selalu berusaha mengatasi kebutuhan dirinya sendiri. Hal inilah yang menambah nilai kemanusiaan bagi mereka dan adanya dinamika kehidupan bagi mereka.Pengkajian berikut adalah lebih membahas dorongan-dorongan untuk kemauan berusaha dari mereka yang tergolong disabilitas kecerdasan.

\section{PEMBAHSAN}

\section{Disabilitas Kecerdasan}

Disabilitas kecerdasan adalah suatu label atau penyebutan yang digunakan bagi mereka yang tergolong memiliki hambatan di bidang kecerdasan. Istilah lain dengan sebutan tunagrahita, cacat mental, atau retardasi mental (mental retardation). Kecenderungan mereka disebut disabilitas kecerdasan untuk lebih memberi tanda perbedaan dengan mereka yang mengalami hambatan belajar lainnya yang disebabkan oleh hambatan bukan kecerdasan. Disabilitas kecerdasan ini dikemukakan oleh American Association on Intellectual and Developmental Disabilities (AAIDD) melalui Schalock et al., 2010 (Kauffman \& Hallahan, 2011, p. 176) "characterized by significant limitation both in intelectual functioning and in adaptive behavior as expressed in conceptual, social, and practical adaptive skills." Definisi akhir itu hampir sama substansinya dengan definisi-definisi sebelumnya tentang hambatan yang dialami oleh disabilitas kecerdasan, hanya lebih menekankan kenampakan hambatan pada keterampilan konseptual, sosial, dan adaptif.

Definisi sebelumnya yang dikemukakan oleh American Association Mental Deficiency (AAMD) pada tahun 1973 mengalami perubahan. Hal itu dikemukakan Grossman (Smith, 2002, p. 50) ada dua kriteria dari inidividu yang dianggap retardasi mental yaitu satu kecerdasan di bawah rata-rata dan kedua 
pada kekurangan adaptasi tingkah laku yang terjadi selama masa perkembangan. Selanjutnya, tahun 1992 AAMD mengalami perubahan menjadi American Association Mental Retardation (AAMR), demikian juga definisi yang dikemukakan oleh Ruth Luckasson (Smith et.all., 2002, p. 56) bahwa individu dianggap terbelakang mental jika memenuhi dua kriteria, yaitu keterbelakangan atau kekurangan dalam adaptasi tingkah laku dan kekurangan penyesuaian diri dengan lingkungannya diukur dengan taraf usia menurut kalender yang telah dicapai seseorang anak. Itulah yang menjadi penekanan berbagai definisi tentang anak terbelakang atau hambatan mental. Keterbelakangan tersebut meliputi segala aspek yang meliputi 10 bidang keterampilan adaptif, yaitu: komunikasi, menolong diri sendiri, keterampilan kehidupan di keluarga, keterampilan sosial, kebiasaan di masyarakat, pengarahan diri, menjaga kesehatan dan keamanan diri, akademik fungsional, waktu luang dan kerja.

Perbandingan antara definisi AAIDD dan AAMR terletak pada penjabaran tentang aspek kelemahan konseptual, sosial, dan keterampilan adaptif. Jika AAMR sebelumnya menjabarkan menjadi 10 hambatan di bidang keterampilan adaptif, sebenarnya juga representasi dari kelemahan konseptual, sosial, dan keterampilan adaptif. Keterampilan adaptif inilah yang dikaitkan dengan standar budaya, sehingga kemandirian lebih diorientasikan untuk keterampilan adaptif sesuai dengan budaya. Hal tersebut juga dapat ditinjau bahwa kelemahan mereka adalah: Pertama, defisit fungsi intelektual, seperti ketidakmampuan dalam berrasional, pemecahan masalah, perencanaan, berpikir abstrak, pertimbangan, belajar akademik, dan mengambil belajar dari pengalaman. Kedua, defisit dalam fungsi keterampilan adaptif sebagai akibat kegagalan yang diukur secara perkembangan dan standar sosio-kultural pada kemandirian pribadi dan tanggung jawab sosial. Tanpa dukungan yang terus-menerus akan mengalami defisit yang terbatas pada bidang satu atau dua aktivitas kehidupan sehari-hari, seperti komunikasi, partisipasi sosial, dan kemandirian dalam lingkungan yang bervariasi seperti keluarga, sekolah, dan masyarakat. Persoalan-persoalan itulah yang perlu menjadi titik tolak untuk lebih dimodifikasi tentang makna kemandirian bagi mereka, sehingga karakter mandiri pada mereka bermakna optimalisasi kemanusiaan mereka.

\section{Pendidikan dan Kemandirian}

Makna mandiri dapat diartikan sebuah konsep tentang otonomi atau kesadaran diri beraktualisasi dalam kehidupan. Sumarna (2013, p. 14) bahwa kemandirian, otonomi, dan kedaulatan merupakan tiga kata yang saling berkaitan.Namun demikian, menentukan mandiri sebagai arah pendidikan adalah mandiri yang disertai tindakan reflektif dan pertimbangan yang matang.Tindakan yang disertai pertimbangan dan refleksi terhadap kondisi sekitar dan nilai-nilai yang dijunjung tinggi dalam budaya, sehingga tindakan itu memberi arah bagi kebaikan lingkungan dan menjunjung nilai-nilai yang dipedomani oleh budaya masyarakat di tempat tinggal subyek didik. Hal itu jika telah dicapai akan berimplikasi kepercayaan terhadap subyek didik tentang otonomi dan kedaulatan menentukan arah dalam tindakan-tindakan selama kehidupan.

Pendidikan sebagai upaya memanusiakan manusia merupakan juga pembentukan kemandirian dalam kapasitas kemanusiaan. Kemandirian itu harus dilaksanakan oleh pribadi hasil didik yang memiliki karakter mandiri. Pribadi yang secara merdeka dapat menentukan atau memutuskan tindakantindakan yang akan dilakukan dengan pertimbangan nilai-nilai yang diyakini memberi manfaaat bagi segala aspek kehidupan. Tilaar (2005, pp. 110-111) bahwa tujuan pendidikan ditentukan secara merdeka oleh manusia, namun juga terikat oleh ikatan kehidupan manusiawi.Tujuan pendidikan pada masa kanakkanak ditentukan orang tua yang melahirkan, semakin berkembang remaja mulai ditentukan oleh masyarakat di tempat individu menjadi anggotanya.Selanjutnya, individu dewasa tujuan pendidikan ditentukan oleh pribadi itu sendiri.Jelaslah bahwa pendidikan sebagai upaya pembentukan pribadi yang mandiri dengan mampu pertimbangan nilai-nilai kemanusiaan dalam habitus kemanusiaan.

Nilai-nilai habitus kemanusiaaan adalah representasi dari kehidupan itu sendiri. Untuk itu, Driyarkara (Siswoyo, 2013, p. 57) menegaskan pendidikan sebagai fenomena yang fundamental atau asasi dalam kehidupan manusia, karena nilai-nilai yang akan dicapai 
juga nilai-nilai kehidupan manusia itu sendiri. Kehidupan yang dipertahankan adalah kehidupan yang bernilai, sehingga dasar kemandirian adalah kemampuan untuk memutuskan kehidupan yang bernilai.Pembentukan karakter mandiri merupakan usaha mendialogkan kepada peserta didik untuk menjalankan kehidupan yang bernilai. Saat dialog tentang kehidupan yang bernilai tersebut pembimbing dapat melalui menunjukkan dengan perbuatan, mengajak melaksanakan, membantu untuk berbuat, atau mengajak mendiskusikan tentang substansi hal yang dimaksud kehidupan bernilai. Peserta didik diberikan kesempatan untuk memutuskan sendiri atau diberi keleluasaan memilih tentang kehidupan yang bernilai. Cara itu sebagai alternatif model pembinaan karakter kemandirian.Model berpijak pada konteks kehidupan karena dalam kehidupan itu sendiri terdapat substansi yang menjadi tujuan kehidupan bernilai.

\section{Sosialisasi di Ekologi Keluarga, Sekolah, dan Masyarakat}

Pijakan kehidupan sebagai konteks terdapatnya substansi kemandirian peserta didik adalah ekologi tempat berkembangnya peserta didik. Ekologi tersebut sebagai tempat peserta didik melaksanakan sosialisasi, karena proses dialog tentang substansi nilai kehidupan itu sendiri melalui sosialisasi. Urie Bronfenbrenner (Berns, 2005, p. 14) "believes that the social context of individual interaction and experiences determines the degree to which individuals can develop their abilities and realize their potentials". Pendapat tersebut menganalogikan bahwa konteks tempat peserta didik bersosialisasi menentukan perkembangan kemampuan dan merealisasikan potensinya. Konteks kehidupan sesuai teori Bronferbrenner tersusun menjadi empat struktur, yaitu: microsystem, mesosystem, exosystem, dan makrosistem. Empat stuktur itu sebagai pola-pola interaksi dan hubungan peserta didik yang berpengaruh pada perkembangannya.System-sistem itu terbangun dikarenakan pola-pola interaksi perkembangan anak dalam lingkungan keluarga, sekolah, dan masyarakat.

Pada struktur system micro merupakan penunjuk tentang aktivitas dan hubungan dengan lainnya secara signifikan dialami oleh anak dalam setting keluarga, sekolah, kelompok sebaya, dan masyarakat.Pada setting keluarga tersedia bimbingan, kasih sayang, dan bermacam-macam kesempatan. Ha itu yang utama sebagai agen sosialisasi dari anakanak yang lebih berarti bagi perkembangan anak. Sekolah sebagai system mikro adalah tempat anak pertama kali belajar formal tentang masyarakat mereka.Tempat diajarkan membaca, menulis, menghitung, sejarah, pengetahuan alam, serta guru mendorong perkembangan berbagai macam keterampilan yang mendorong anak sukses belajar.Pada setting teman sebaya adalah sebagai wahana untuk memperoleh kemandirian. Setting teman sebaya sebagai area mendapatkan pengalaman belajar kerja sama dan menerima peranannya. Selanjunya, masyarakat atau tetangga terdekat juga bermakna system micro karena anak-anak belajar tentang cara menggunakan fasilitas di masyarakat. Cara-cara untuk secara nyata menggunakan perpustakaan, toko tempat belanja, dan tempat yang terdekat dengan anak dan dapat mengobservasi ketika orang bekerja, berhubungan dengan bermacam-macam sifat orang.

Pada sistem meso, ialah hubungan dan interrelasi antara dua atau lebih pada setting micro, yaitu antara keluarga dan sekolah, dan antara keluarga dan kelompok sebaya. Misalnya anak pergi ke sekolah sendirian di suatu hari. Hal ini maknanya anak tidak hanya hubungan tunggal antara rumah dan sekolah, melainkan sosialisasi nilai, harapan, pengalaman, dan juga kecenderungan pencapaian akademik dari anak. System meso ini menyediakan dukungan untuk system micro berkembang.

Pada system exo merupakan setting yang menunjukkan anak-anak tidak sebagai partisipan aktif, tetapi berpengaruh pada system mikro.Contoh pekerjaan orang tua, ini memberi pengaruh pada pola hidup orang tua dan cara-cara untuk mengarahkan anaknya. Jika orang tua bekerja pada setting yang mendukung self-direction, mereka memiliki model untuk mengarahkan anaknya secara demokratis. System exo ini sifatnya secara tidak langsung sebagai agen sosialisasi bagi perkembangan anak. Anak tidak aktif belajar dari kehidupan itu secara nyata, tetapi mendapatkan sosialisasi dari orang sekitarnya dikarenakan orang tersebut juga akibat pengaruh di-setting mereka beraktivitas. Selanjutnya, pada sistem makro adalah system secara luas dari masyarakat dan sub-subbudayanya. 
Sub-sub itu meliputi: keyakinan dan system nilai, gaya hidup, serta perubahan teknologi. System ini secara tidak langsung juga berpengaruh pada perkembangan anak.

Struktur system ekologi yang telah tersebut sebagai lapis-lapis perkembangan sosialisasi peserta didik. Sosialisasi memegang peranan penting dalam perkembangan anak, karena Berns (2005, p.34) mengemukakan:

\begin{abstract}
"Socialization enables children to learn what they need to know in order to be integrated into the society in which they live. It also enables them to develop their potentialities and form satisfying relationships. Through socialization, children develop a self-concept, learn self regulation, empower achievement, acquire appropriate social roles, and developmental skills".
\end{abstract}

Peran penting sosialisasi untuk mendorong perkembangan anak ini menunjukkan bahwa menuju kemandirian diharuskan peserta didik melalui sosialisasi. Proses itu dilaksanakan dalam ekologi peserta didik. Ekologi peserta didik adalah agen-agen sosialisasi peserta didik, yaitu keluarga, sekolah, kelompok sebaya, dan masyarakat. Keluarga adalah mengantarkan anak ke masyarakat, dan selanjutnya, merupakan pertanggungjawaban pokok yang mensosialisasikan anak. Selanjutnya, sekolah ialah agen masyarakat dan diorganisasikan untuk melangsungkan pengetahuan, keterampilan adat-istiadat, dan kepercayaan. Sosialisasi anak melalui sekolah untuk perubahan bagi masyarakat, dan itu sebagai tantangan yang berkelanjutan. Untuk itu, sekolah sebagai agen sosialisasi menjamin generasi penerus yang selalu belajar menghadapi perubahan. Agen sosialisasi berikutnya meliputi teman sebaya, media masa, serta masyarakat. Walaupun setiap agen sosialisasi tersebut memiliki fungsi masing-masing, namun mereka harus selalu kerja sama secara berkesinambungan dan kolaboratif membina perkembangan anak. Hal itu dibutuhkan agar supaya perkembangan anak dapat saling mendukung ke arah tujuan, khususnya tujuan mandiri dalam konteks sistem ekologi kehidupan.

\section{Kemandirian Disabillitas Kecerdasan}

Kemandirian bagi peserta didik yang menyandang disabilitas kecerdasan adalah persoalan yang unik.Nilai kemandirian me- rupakan otonomi dan kemampuan pengambilan keputusan untuk menjalankan kehidupan memerlukan individu mampu berasional, hal itu menjadi hambatan yang dimiliki oleh peserta didik disabilitas kecerdasan. Modifikasi nilai kemandirian merupakan solusi arah pendidikan bagi penyandang disabilitas kecerdasan. Modifikasi terletak pada substansi, namun konteks kehidupan secara ekologis tetap merupakan sistem antara keluarga, sekolah, dan masyarakat. Sistem tersebut mendasari pembahasan tentang substansi kehidupan yang menjadi tujuan-tujuan belajar. Substansi kehidupan yang membutuhkan kompetensi untuk diolah dan dijaga keberlangsungannya. Secara ekologis kehidupan yang dikemukakan oleh Bronfenbrenner (Berns, 2004, p. 3) adalah yang mengkaji hubungan individu dan lingkungannya secara biologis, psikologis, sosial, dan budaya di dalam keluarga, sekolah, dan masyarakat. Pijakan ketiga tempat kehidupan seorang anak berkembang, namun taraf berkembang agar supaya mandiri di tiga tempat tersebut bagi peserta didik disabilitas kecerdasan membutuhkan modifikasi dan model spesifik dalam pembelajarannya.

Ekologi kehidupan peserta didik dalam keberlangsungannya dibangun oleh pengisi kehidupan, salah satunya peserta didik disabilitas kecerdasan.Mereka dapat diarahkan untuk memiliki kompetensi kemandirian dengan pendekatan belajar dalam konteks yang berkaitan dengan kegiatan-kegiatan di dalam kehidupan itu sendiri. Hal itu juga didasari oleh model yang diajukan Brown dan koleganya di tahun 1979 dengan pengem-bangan kurikulum yang disebut: "chronologically age-appropriate functional skills in natural environments". Model ini secara luas diketahui sebagai "kurikulum fungsional." Model ini tidak seperti model kurikulum perkembangan sebelumnya, pada saat itu diasumsikan suatu premise bahwa siswa dengan kognitif disabilitas dapat belajar secara terampil pada fungsi yang sama di lingkungan temannya yang bukan disabilitas. Hal itu juga penting, sebagai persiapan di sekolah menengah dalam setting yang mereka butuhkan untuk masa dewasa. Keterampilan fungsional (functional skills) merupakan keterampilan yang dibutuhkan sehari-hari di lingkungan keluarga, sekolah, dan masyarakat. Ketiga sumber lingkungan dalam aktivitas kegiatan kehidupan seharihari dibagi menjadi empat domain: yaitu 
domestic, leisure/recreation, community, dan vocational. Lingkungan yang alamiah tersebut merupakan dua sumber, yaitu sumber konten kurikulum dan sumber lokasi keterampilan yang harus dipelajari. Model kurikulum fungsional ini sesuai teori ekologi sosialisasi perkembangan anak, yaitu ekologi dalam setting keluarga, sekolah, dan masyarakat.

Modifikasi kemandirian disabilitas kecerdasan adalah mengubah aktivitas-aktivitas kehidupan di lingkungan ketiga setting dengan menyesuaikan kondisi keterbatasan kecerdasan disabilitas kecerdasan. Keterbatasan keterampilan pada adaptif diarahkan untuk lebih intensif pada bidang-bidang keterampilan adaptif dalam setting keluarga, sekolah, dan masyarakat. Dukungan hasil penelitian yang dilakukan Brown dan kawan-kawan di tahun 1979 bahwa keterampilan adaptif tersebut fungsional atau tidak fungsional bergantung cara dan tempat keterampilan itu diajarkan. Maksudnya keterampilan adaptif yang diajarkan karus dalam konteks kehidupan, dan untuk itu keterampilan tersebut disebut "kecakapan hidup/life skills". Istilah tersebut digunakan untuk mendeskripsikan tipe-tipe keterampilan yang diajarkan yang meliputi keterampilan domestik, keterampilan waktu luang/leisure and recreation, keterampilan kehidupan di masyarakat/community use, dan pemilihan keterampilan. Tipe-tipe keterampilan-keterampilan hidup yang perlu diajarkan di dalam konteks kehidupan peserta didik disabiltas kecerdasan inilah yang selanjutnya menjadi arah kemandirian disabilitas kecerdasan.

\section{Kecakapan Hidup Disabilitas Kecerdasan dan Pembentukan Karakter Mandiri dalam Konteks Kehidupan Keluarga, Sekolah, dan Masyarakat}

Karakter adalah pembentukan sifatsifat yang menjadi ciri khas individu.Sifatsifat yang menjadi penciri pembentuk pribadi berasal dari hal-hal yang bernilai dalam kehidupan.Demikian itu dikemukakan oleh William Berkovitsz melalui Suyata (Zuchdi, 2011, pp. 14-15) bahwa karakter serangkaian ciri-ciri psikologis individu yang mempengaruhi kemampuan pribadi dan kecenderungan berfungsi secara moral. Fungsi moral inilah bahwa pembentuk pribadi bersumber dari hal yang bernilai. Pribadi yang berkarakter adalah pribadi yang memiliki tanda sifat- sifat bernilai, jika karakter dipandang sebagai "alat untuk menandai/tool for marking" demikian menurut (Hamengku Buwono, 2012, p. 4).Nilai-nilai kemandirian sebagi pembentuk karakter mandiri adalah berasal dari kemampuan individu dalam mengatasi persoalan hidup secara otonomi. Kemampuan tersebut memberi manfaat bagi kehidupan dalam ketiga setting kehidupan peserta didik, yaitu keluarga, sekolah, dan masyarakat. Peserta didik sudah mampu mengambil tindakan-tindakan yang mencirikan penggunaan dayanya sendiri (self-power) mengatasi persoalan hidup. Demikian tersebut, dasar pembentukan karakter mandiri peserta didik disabilitas kecerdasan bahwa kapasitas kemanusiaan pribadi (selfhumanity-power) bermanfaat bagi kehidupan pribadi dan lingkungan.

Pembentukan pribadi dengan karakter mandiri bagi peserta didik disabilitas kecerdasan dibutuhkan pembelajaran.Pembelajaran dilaksanakan melalui pembinaan kapasitas kecakapan hidup dalam konteks kehidupan keluarga, sekolah, dan masyarakat. Masingmasing tipe keterampilan kecakapan hidup tersebut dibahas sebagai berikut:

Pertama, keterampilan domestik. Tipe keterampilan ini dibatasi oleh Snell (Hallahan \& Kauffman, 2011, p. 558) merupakan selfcareskills yang terdiri dari keterampilan memelihara kesehatan dan kebersihan dirinya sendiri, berpakaian, dan makan. Kemampuan untuk mandiri dalam bidang ini meningkatkan penampilan bersih dan sehat sehingga dapat diterima oleh kelompok sebaya dan membentuk gambaran diri yang positip. Kemandirian untuk memelihara diri ditentukan sesuai dengan usia kronologis peserta didik dan ini diajarkan dalam konteks kebiasaan yang dilakukan sehari-hari baik di lingkungan keluarga maupun lingkungan sekolah. Keterampilan berikutnya pada domain ini adalah keterampilan kerumah-tanggaan. Keterampilan ini perlu diajarkan secara natu-ral melalui rutinitas di rumah dan sekolah. Pendapat tersebut dari hasil dari review yang dilakukan Lancioni dan O'Reilly (2002, pp. 236-253) terhadap 16 pengkajian penggunaan gambar berseri, 7 studi dengan analisis tugas, dan 4 studi menggunakan kombinasi promting dengan gambar dan penundaan waktu tentang mengajarkan menyiapkan makanan. Demikian juga, penelitian tentang menolong diri yang rutin dilatihkan dari hasil penelitian Suriadi, Dantes, \& 
Marhaeni (2013) dan penggunaan analisis tugas dalam belajar kebiasaan buang air kecil dan buang air besar (toilettraining) dari penelitian Panjaitan, Irdamurni, Kasiyati (2013). Semua hasil peninjauan dari pembelajaran keterampilan kategori domestik tersebut perlu dilakukan dengan rutinitas sehari-hari agar terbentuk sifat-sifat mandiri langsung dalam konteks kebutuhan peserta didik dalam kehidupan sehari-hari.

Kedua, kemandirian dalam aktivitas waktu luang/rekreasi. Penyandang disabilitas kecerdasan keterampilan untuk mengisi waktu luang merupakan problem sendiri. Mereka tidak mampu menciptakan kegiatan-kegiatan yang memberikan rasa relaksasi, senang, dan hiburan. Kegiatan ini perlu dikondisikan dalam konteks lingkungan rumah, keluarga, dan masyarakat berbagai kegiatan rekreasi, sehingga pengkondisian yang rutin memberikan pembentukan kemandirian dalam mengisi kebutuhan waktu luang.

Ketiga, Kemandirian keterampilan kehidupan masyarakat. Bidang-bidang kemandirian dalam keterampilan ini meliputi: berbelanja di pasar, warung, dan toko, melakukan perjalanan dengan kendaraan umum, menggunakan pusat-pusat kesehatan dan fasilitas umumnya. Kemandirian dalam bidang ini perlu diajarkan secara simultan dan simulasisimulasi dalam konteks nyata di tempat fasilitas umum itu secara langsung.

Keempat, pengarahan diri (self-determination). Keterampilan ini lebih menentukan bagi disabilitas kecerdasan, karena keputusan dalam memilih kegiatan yang perlu dilakukan sehari-hari terletak pada kemampuan ini. Wehmeyer (Hallahan \& Kauffman, 2011, p. 560) mendefinisikan self-determination adalah "voliotional actions that enable one to act as the primary causal agent in one's life and to maintain or improve one's quality of life." Keterampilan ini membentuk keterampilan-keterampilan kepribadian yang lain seperti: choice making, problem solving, decision making, goal setting dan attainment, self-management dan self-regulation, selfadvocacy dan leadership, serta self-awareness dan self-knowledge; (e) Penetapan keterampilan yang dibutuhkan untuk vokasional/kejuruan untuk ditekuni. Pemilihan keterampilan ini perlu mempertimbangkan usia, kondisi fisik siswa, kecenderungan dan masa depan lingkungan masyarakat, fungsi dari keteram- pilan itu sendiri, pilihan dan minat dari orang tua maupun siswa itu sendiri.

Bidang-bidang kecakapan hidup tersebut perlu dirancang sebagai program pembentukan karakter mandiri dari peserta didik disabilitas kecerdasan.Pembentukan dalam konteks kehidupan keluarga, sekolah, dan masyarakat menjadi agen pembelajaran yang secara nyata tempat untuk berlatih dan membiasakan tumbuhnya karakter mandiri bagi peserta didik disabilitas kecerdasan.

\section{PENUTUP}

Karakter mandiri pada peserta didik disabilitas kecerdasan adalah terbentuknya kepribadian dari mereka dengan perilaku-perilaku yang mampu melakukan dan mengatasi masalah kehidupan sehari-hari dalam lingkungan keluarga, sekolah, dan masyarakat. Pembelajaran untuk pembentukan karakter mandiri dibutuhkan mampu bersosialisasi dalam ekologi kehidupan keluarga, sekolah, dan masyarakat.Karakter mandiri tersebut sebagai wujud aktualisasi kemanusiaan dengan menjalankan kehidupan yang dengan nilai adaptif dan fungsional.

\section{DAFTAR PUSTAKA}

Berns. Roberta M. (2005). Child, family, school, community. Socialization and support. Belmont: Thomson Learning.

Brown, L, Branston, M. B., Hamre-Nietupski, S., Pumpian, I., Certo, N., \& Grunewald, L. (1979).A strategy for developing chronological-ageappropriate and functional curricular content for severely handicapped adolescent and adults. Journal of Special Education, 13, 81-90.

Hamengku Bowono X. (2012). Membangun Insan yang Berkarakter dan Bermartabat. Pidato Dies. Disampaikan pada Peringatan Dies Natalis 6 Windu Universitas Negeri Yogyakarta pada tanggal 21 Mei 2012. Yogyakarta: Universitas Negeri Yogyakarta.

James M. Kauffman \& Daniel P. Hallahan (2011). Handbook of Special Education. New York: Routledge. 
Lancioni, G. E., \& O'Reilly, M.F. (2002). Teaching food preparation skills to people with intellectual disabilities: A literature overview. Journal of Applied Research in Intellectual Disabilities.15, 236-235.

Panjaitan, R. A. A., Irdamurni, Kasiyati. (2013). Meningkatkan kemampuan toilet training melalui analisis tugas pada anak tunagrahita sedang.Padang: E-JUPEKhu, Volume 3, Nomor 3 September 2013.

Pratiwi, N. H. (2011). Peran yayasan dalam menumbuhkan kemandirian anak tunagrahita (Studi Evaluasi pada Yayasan Sang Timur dan Yayasan Amal Mulia). Yogyakarta: Skripsi Jurusan Pembangunan Sosial dan Kesejahteraan Fakultas Ilmu Sosial dan Ilmu Politik Universitas Gajah Mada.

Siswoyo, D., dkk. (2013). Ilmu Pendidikan. Yogyakarta: UNY Press.
Suriadi, N. M., Dantes, N., \& Marhaeni, A. A. I. N. (2013). Penerapan metode drill untuk meningkatkan aktivitas belajar dan kemampuan mengurus diri sendiri bagi anak tunagrahita. Singaradja: e-journal Program Pascasarjana Universitas Pendidikan Ganesha Jurusan Pendidikan Dasar. Volume 3 Tahun 2013.

Smith, M.B., Ittenbach, R.F., \& Patton, J.R. (2002). Mental retardation. 6th ed. New Jersey: Merrill Prentice Hall.

Sumarna. (2013). Pendidikan untuk Pencerahan dan Kemandirian Bangsa. Pidato Dies Natalis ke-49 Universitas Negeri Yogyakarta.

Tilaar. (2005). Manifesto pendidikan nasional. Tinjauan dari Perspektif Postmodernisme dan studi kultural. Jakarta: Kompas.

Zuchdi, Darmiyati. (Ed). (2011). Pendidikan Karakter dalam Perspektif Teori dan Praktek. Yogyakarta: UNY Press. 